\title{
BADANIA DOŚWIADCZALNE ZGINANYCH BELEK WYKONANYCH Z BETONÓW LEKKICH ZBROJONYCH SIATKĄ SPAWANĄ
}

\begin{abstract}
Belkowe elementy konstrukcyjne z pianobetonu i gazobetonu zazwyczaj są wykonywane jako jednolite, a do ich wzmacniania wykorzystywane są stalowe pręty o profilu gładkim lub żebrowanym. Badania eksperymentalno-teoretyczne elementów wykonanych $\mathrm{z}$ betonów lekkich zbrojonych niekonwencjonalnym zbrojeniem, w tym metodyka obliczania takich konstrukcji, są mało znane, a stosowanie takich elementów w praktyce jest rzadko spotykane. Jednym z rodzajów niekonwencjonalnego rozwiązania problemu zbrojenia elementów z betonów lekkich jest zamiana tradycyjnego zbrojenia na materiały pochodzenia biologicznego lub/i organicznego oraz stosowanie różnego rodzaju siatek. W artykule przedstawiono wyniki badań eksperymentalnych i analiz teoretycznych gazożużlobetonowych zginanych elementów belkowych zbrojonych stalowymi siatkami spawanymi. Pokazano niektóre wyniki badań eksperymentalnych wytrzymałości takich elementów poddanych obciążeniom.
\end{abstract}

Słowa kluczowe: gazobeton, żużlobeton, niekonwencjonalne zbrojenia, wytrzymałość, nośność, deformacje

\section{Wprowadzenie}

Potrzeba stosowania elementów konstrukcyjnych z betonów lekkich jest uzasadniona szeregiem badań i analiz oraz potwierdzona doświadczeniami w praktyce budowlanej Ukrainy, Polski, Niemiec i innych krajów [1, 2, 3]. $\mathrm{W}$ wielu $\mathrm{z}$ tych krajów lekkie betony są szeroko stosowane zarówno w budownictwie mieszkaniowym, jak i przemysłowym.

Najbardziej popularnymi wśród lekkich betonów w budownictwie są pianobeton i gazobeton, które pozwalają na znaczne zmniejszenie kosztochłonności

\footnotetext{
${ }^{1}$ Autor do korespondencji/ corresponding author: Sofiya Burchenya, Ivan Dobryanskyy, Yuriy Famulyak, Wydział Budownictwa i Architektury, Lwowski Narodowy Uniwersytet Rolniczy, e-mail: yufam@ukr.net

${ }^{2}$ Justyna Sobczak-Piąstka, Wydział Budownictwa, Architektury i Inżynierii Środowiska, Uniwersytet Technologiczno-Przyrodniczy im. Jana i Jędrzeja Śniadeckich w Bydgoszczy
} 
zarówno budownictwa mieszkaniowego jak i przemysłowego $\mathrm{w}$ stosunku do tradycyjnych rozwiązań. W celu uzyskania porowatej struktury w betonach komórkowych są wykorzystywane głównie dwa sposoby: dodawanie do wodnej suspensji zmieszanych materiałów dodatków gazotwórczych lub mieszaniny suspensji z pianą. Materiał produkowany pierwszym sposobem jest nazywany gazobetonem, drugi zaś - pianobetonem. Rolę spoiwa w tych betonach komórkowych pełni za każdym razem cement.

Produkty z pianobetonu lub gazobetonu są przeznaczone do murowania ścian zewnętrznych i wewnętrznych, do wykonywania izolacji cieplnej poddaszy, podłóg, wypełniania różnego rodzaju pustek, konstruowania izolacji dźwiękowej stropów itp. [4, 5]. Produkcja takich elementów jest w zasadzie dość popularna, stosunkowo niedroga, a powstałe elementy mają wystarczające właściwości ciepłochronne i dźwiękoizolacyjne oraz są bezpieczne ekologicznie. Poza tym takie wyroby można ciąć i poddawać innej obróbce bez większych kłopotów.

Pianobeton i gazobeton oraz inne materiały produkowane przy zastosowaniu cementu, dojrzewając z upływem czasu zwiększają swoją wytrzymałość [6]. Obecność porów zapewnia uzyskanie kilku ważnych właściwości, takich jak: niska przepuszczalność ciepła, mała waga i łatwość obróbki.

Ze względu na swoje właściwości, beton komórkowy kwalifikowany jest do betonów kruchych. W związku z tym utrudnione jest jego stosowanie bez dodatkowych wzmocnień, które przejmowałyby naprężenia rozciągające w zginanych konstrukcjach, a dodatkowo nie redukowały ich wytrzymałości na ściskanie. Ma to szczególnie duże znaczenie w elementach osiowo i mimośrodowo ściskanych.

Istniejące prace i badania dotyczą głównie elementów konstrukcyjnych wykonanych z jednolitego betonu komórkowego bez wzmocnienia, ewentualnie $\mathrm{z}$ tradycyjnym zbrojeniem $\mathrm{w}$ postaci prętów stalowych o profilu gładkim lub żebrowanym. Elementy $\mathrm{z}$ betonu lekkiego, które pozwolą $\mathrm{w}$ jednym profilu kompleksowo połączyć lekkość, dobre właściwości ciepłochronne i dźwiękoizolacyjne oraz wytrzymałościowe to takie elementy, które dodatkowo są zbrojone niekonwencjonalnym zbrojeniem. Może to być na przykład elastyczne lub sztywne zbrojenie pochodzenia biologicznego lub organicznego, różnorodne typy siatek metalicznych i niemetalicznych, itp. [7]. Stosowanie tego typu elementów nie jest powszechne w praktyce budowlanej, a związane jest to głównie z brakiem przeprowadzonych kompleksowych badań i analiz tego typu materiałów. W pracy zostaną przedstawione badania i analizy gazobetonowych belek wzmocnionych stalową siatką spawaną, zabezpieczoną specjalną otuliną z żużlobetonu.

\section{Przeprowadzone badania laboratoryjne}

W celu wykonania kompleksowych badań elementów gazobetonowych poddanych zginaniu, wzmocnionych dodatkowo niekonwencjonalnym zbrojeniem w postaci stalowej spawanej siatki (rys. 1) oraz określenia jej wpływu na 
wytrzymałość i nośność, zostały przeprowadzone badania eksperymentalne wzorcowych belek z różnym rozkładem zbrojenia.

Do wykonania wzorcowych belek wykorzystano gazobeton, który służył jako rdzeń belki (rys. 2) oraz żużlobeton, z którego stworzono zewnętrzną powłokę belki wzorcowej. Żużlobeton należy do lekkich betonów konstrukcyjnych lub wypełniających, w których zastosowano żużel hutniczy uprzednio rozdrobniony, przesiany i oczyszczony ze szkodliwych zanieczyszczeń. Zastosowanie żużlobetonu, jako powłoki zewnętrznej belki gazobetonowej spowodowane jest tym, że taki materiał jest tani oraz ma prostą technologię wytwarzania w odróżnieniu od produkcji gazobetonu.

Gazobetonowy rdzeń belki wzorcowej wykonano z gotowego gazobetonowego bloku firmy «Stoyn Late» (Browary, obwód Kijowski). Gotowy blok gazobetonowy rozcięto na belki o długości $60 \mathrm{~cm}$ i przekroju o wymiarach $4 \times 8 \mathrm{~cm}$. Zewnętrzna zabezpieczająca warstwa została wykonana $\mathrm{z}$ betonu żużlowego o grubości $2 \mathrm{~cm}$. Żużlobeton mieszano w następującej proporcji: 7 części żużlu, 2 części piasku, 1,5 części cementu marki M400 (CEM 32,5) oraz 2 części wody.

Zbrojenie badanych belek stanowiła stalowa spawana siatka o oczkach $10 \times 10 \mathrm{~mm}$ i średnicy prętów $2 \mathrm{~mm}$. Obliczeniowa wytrzymałość na rozciąganie spawanej stalowej siatki wynosi $-\mathrm{R}_{\text {siatki }}=230 M P a$. Stalową siatkę wtapiano w żużlobetonową powłokę badanego elementu wzorcowego (rys. 3).

Fizyko-mechaniczne właściwości gazobetonu i żużelbetonu na ściskanie określono na podstawie rezultatów badań kontrolnych specjalnie wykonanych próbek o wymiarach w przekroju poprzecznym 100×100 mm każda, przy użyciu laboratoryjnej maszyny wytrzymałościowej.

W celu zbadania właściwości zginanych, gazożużlobetonowych belkowych elementów, ze wzmocnioną lub niewzmocnioną żużlobetonową warstwą, zostało zaprojektowanych i wykonanych siedem belek eksperymentalnych. Łączna długość każdej z belek wynosiła $640 \mathrm{~mm}$. Belka gazobetonowa $\mathrm{Nr} 1$ bez warstwy ochronnej $\mathrm{z}$ żużlobetonu miała przekrój 40x80 mm. Pozostałe belki gazobeto-nowe $\mathrm{Nr} \quad 2 \div 7$ miały wykonaną warstwę ochronną $\mathrm{Z}$ żużlobetonu o grubości $20 \mathrm{~mm}$; przekrój poprzeczny tych belek wynosi $80 \times 120 \mathrm{~mm}$. W tej ostatniej grupie belek w warstwie ochronnej zatopiono zbrojenie $\mathrm{w}$ postaci siatek stalowych. Jedna $z$ belek gazożużlobe-tonowych została wykonana bez zbrojenia.

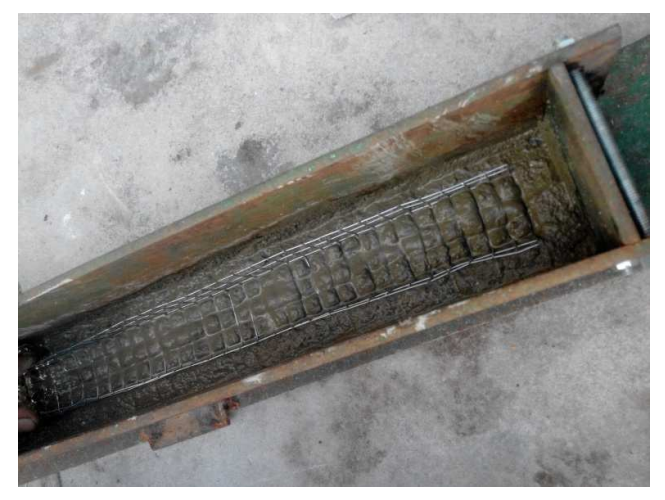

Rys. 1. Siatka zbrojeniowa układana w formie

Fig. 1. Reinforcing grid laid into the form 
Belkowe konstrukcje gazożużlobetonowe wykonywano w składanej metalowej formie. Najpierw w takiej formie układano na spodzie warstwę żużlobetonu o grubości $20 \mathrm{~mm}$, następnie - wkładano przygotowaną płaską lub Ukształtną ramę z siatki spawanej, którą wtapiano na $5 \mathrm{~mm}$ w warstwę żużlobetonu (rys. 1, 2). Następnie na warstwie żużlobetonu i zatopionego w niej wzmocnienia zostaje umieszczona belka z gazobetonu o wymiarach $40 \times 80 \times 600 \mathrm{~mm}$. Boczne przestrzenie pomiędzy belką i formą szczelnie uzupełnia się żużlobetonem tak, aby nie przemieścić pierwotnie ustawionego wzmocnienia z siatki spawanej oraz gazobetonowej belki (rys. 2).

Górna warstwa ochronna z żużlobetonu układana była na gazobetonowej belce po uszczelnieniu żużlobetonu w bocznych przestrzeniach (rys. 3). Wypełnienie bocznej przestrzeni między belką i formą oraz górną warstwę ochronną należy ułożyć jak najprędzej bez przerw technologicznych, w celu uzyskania jednolitości warstwy ochronnej.

Wszystkie uformowane belki przechowywano w odpowiednim temperaturowym i wilgotnościowym reżimie przez $28 \mathrm{dni}$, w celu uzyskania właściwej normowej wytrzymałości.

Badanie gazożużlobetonowych belek na zginanie było prowadzone na stendzie badawczym w laboratorium konstrukcji budowlanych Lwowskiego Narodowego Rolniczego Uniwersytetu. Belki obciążano dwiema skupionymi siłami, przykładanymi w odległości $225 \mathrm{~mm}$ od każdej z podpór badanej belki na jej górnej powierzchni (rys. 4). Belki oparte były na dwóch podporach przegubowych: przesuwnej i nieprzesuwnej. Obciążenie regulowano za pomocą mechanizmu hydraulicznego. Belki przed badaniami dokładnie ustawiano w położeniu pionowym, co pozwoliło pominąć przemieszczenia belek podczas przykładania obciążenia i w czasie ich niszczenia. Ta czynność jest bardzo ważna w celu otrzymania wiarygodnych wyników eksperymentalnych.

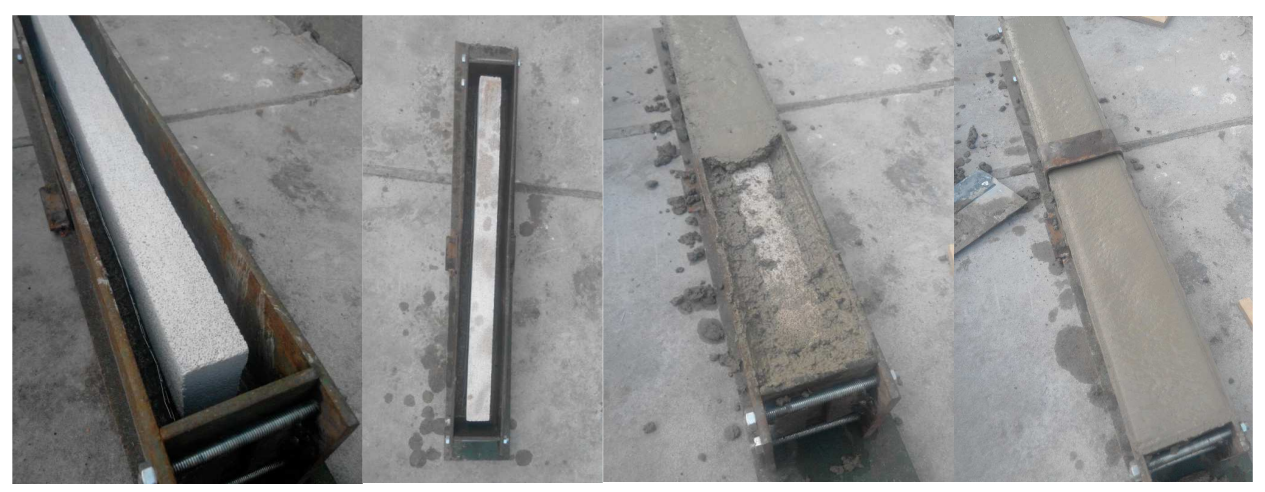

Rys. 2. Wkładanie gazbetonowej belki do formy

Fig. 2. Inserting gas-concrete beam into form
Rys. 3. Układanie górnej warstwy ochronnej z żużlobetonu

Fig. 3. Stacking of the upper protective layer mad slag-concrete 
Ugięcia belek mierzono za pomocą czujnika zegarowego o wartości podziałki $0,01 \mathrm{~mm}$. Czujnik został umieszczony w środkowej części badanego elementu belkowego, na niezależnym statywie, co pozwoliło wykluczyć zewnętrzne wpływy na wskazania pomiarowe w procesie zwiększania obciążenia (rys. 4, 5).

Po każdym wzroście obciążenia, który wynosił $0,50 \mathrm{kN}$, belki utrzymywano pod obciążeniem w ciągu 15-20 minut oraz dokonywano w tym czasie pomiarów przemieszczeń pionowych z czujnika.

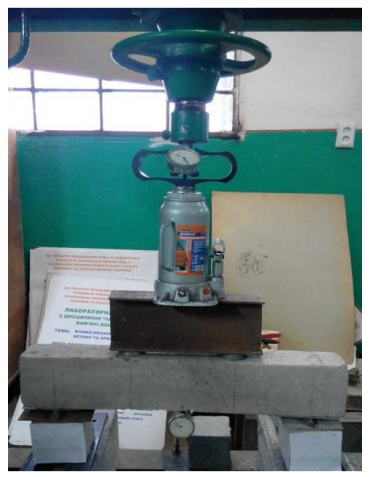

Rys. 4. Stend eksperymentalny do badania gazożużlobetonowych belek

Fig. 4. Experimental stend to study of gas slag concrete beams

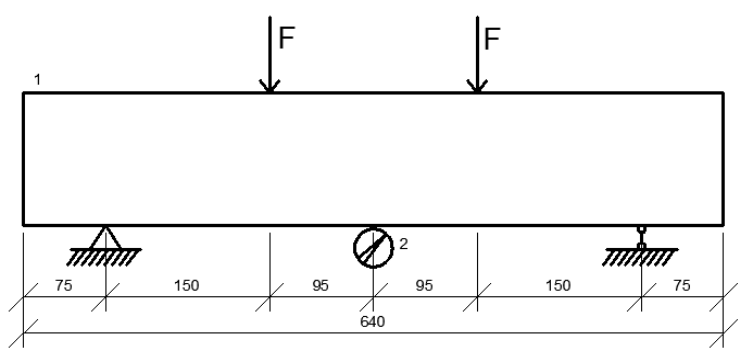

Rys. 5. Schemat rozmieszczenia przyrządów pomiarowych: 1 - gazożużlobetonowa belka, 2 - czujnik pomiaru ugięcia

Fig. 5. Arrangement diagram of measuring instruments: 1 - slag aerated concrete beam, 2 - sensor measuring deflection

W wyniku przeprowadzonych eksperymentalnych badań otrzymano następujące ogólne rezultaty:

- prowadząc badanie belek wzorcowych z warstwą ochronną z żużlobetonu, na początku badań obserwowano etap pierwszy, podczas którego obciążenie powodowało przyrost ugięcia belki, ale nie obserwowano powstawania zarysowań. Zarówno gazobeton, jak i żużlobeton są kruchymi materiałami, więc wytrzymałość na rozciąganie jest dla nich znikoma. W związku z tym proces utworzenia spękań $\mathrm{w}$ belkach wzorcowych $\mathrm{z}$ warstwą ochronną z żużlobetonu (bez wzmocnienia siatką $\mathrm{z}$ prętów spawanych) trwał przez krótki okres lub odbywał się natychmiastowo. Elementy belkowe pracowały do pewnego poziomu obciążenia (etap pierwszy), potem pojawiały się w odległości $((1 / 10-1 / 20) \mathrm{h})$ niewielkie pionowe pęknięcia, praktycznie na całej długości belki (etap drugi);

- po dalszym obciążaniu pojawiało się dominujące pęknięcie, przecinające od $80 \%$ do $100 \%$ wysokości belki wzorcowej, co powodowało rozwój znacznych deformacji i element przechodził w ostatni etap - etap zniszczenia. Na połączeniu gazobetonu i żużlobetonu po zniszczeniu nie zaobserwowano rozwarstwień, ani nieciągłości. 
Belka $\mathrm{nr}$ 1. Jednolita gazobetonowa belka. Przy obciążeniu $0,5 \mathrm{kN}$ ugięcie belki wyniosło $0,37 \mathrm{~mm}$, drugiego etapu pracy betonu belki praktycznie nie było. Przy obciążeniu $0,53 \mathrm{kN}$ belka została zniszczona (uległa złamaniu).

Belka $n r$ 2. Gazożużlobetonowa belka bez zbrojenia. Przy obciążeniu 2,50 $\mathrm{kN}$ maksymalne ugięcie belki wynosiło $1,50 \mathrm{~mm}$. Drugi etap pracy betonu rozpoczął się przy obciążeniu $1,85 \mathrm{kN}$, ugięcie przy tym wyniosło $1,25 \mathrm{~mm}$. Przy obciążeniu 2,64 $k N$ belka została zniszczona (uległa złamaniu).

Belka $n r$ 3. Gazożużlobetonowa belka. Zbrojenie o wyglądzie taśmy ze stalowej spawanej siatki, umieszczonej $\mathrm{w}$ dolnej części belki w warstwie żużelbetonu. Przy obciążeniu 3,00 kN maksymalne ugięcie belki wyniosło $1,13 \mathrm{~mm}$. Drugi etap pracy betonu belki zaczął się przy obciążeniu 2,87 $\mathrm{kN}$, ugięcie przy tym wyniosło $0,89 \mathrm{~mm}$. Przy obciążeniu $3,12 \mathrm{kN}$ belka została zniszczona (uległa złamaniu).

Belka $n r$ 4. Gazożużlobetonowa belka. Zbrojenie o wyglądzie U-podobnego przestrzennego wzmocnienia ze stalowej spawanej siatki w dolnej części belki pod gazbetonowym rdzeniem. Obszar U-podobnego wzmocnienia sięga do 1/3 wysokości gazobetonowego rdzenia belki. Przy obciążeniu 5,50 kN maksymalne ugięcie belki wyniosło $1,56 \mathrm{~mm}$. Drugi etap pracy belki betonowej rozpoczął się przy obciążeniu 4,50 $\mathrm{kN}$, ugięcie przy tym wyniosło $1,21 \mathrm{~mm}$. Przy obciążeniu 5,66 $\mathrm{kN}$ belka została zniszczona. W czasie eksperymentu dostrzeżono pewne cechy charakterystyczne w procesie tworzenia pęknięć belki. Przy zwiększaniu obciążenia obecne były nie tylko pionowe, ale i poziome pęknięcia,

Tabela 1. Schemat niszczenia belek

Table 1. Diagram of destroy beams

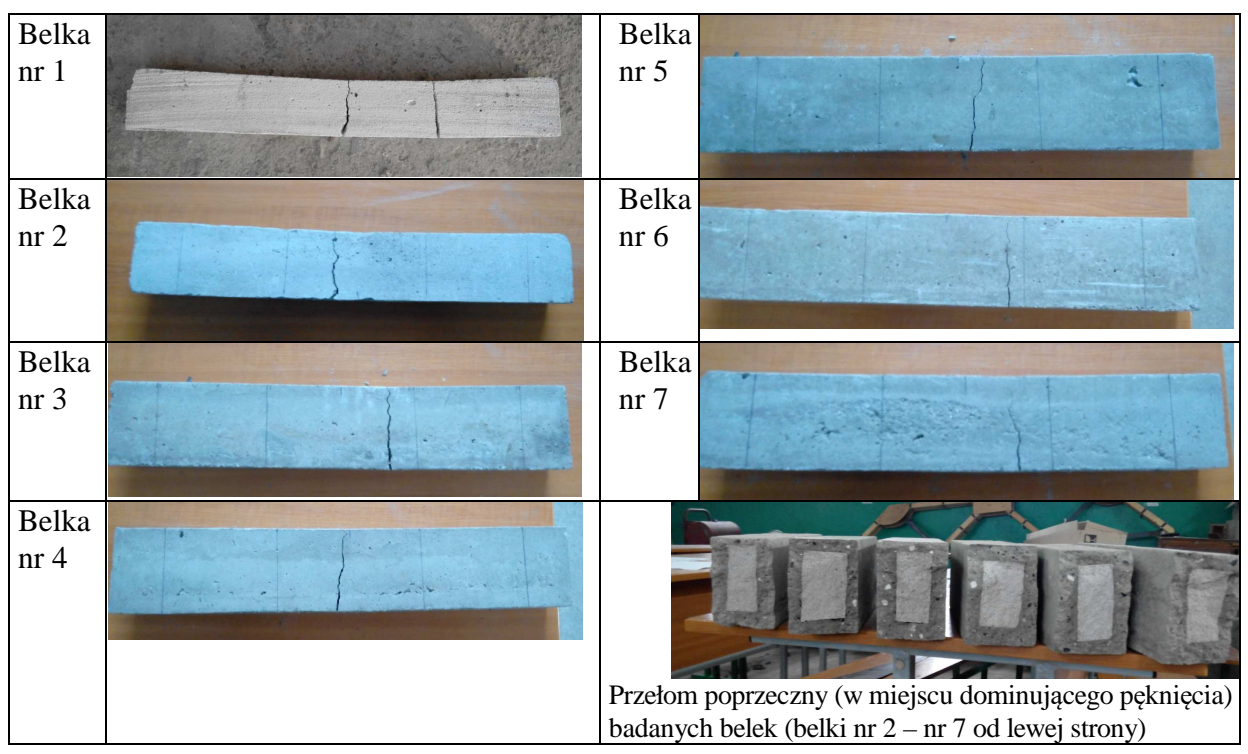


chociaż dominującym było jednak pionowe pęknięcie. Poziome pęknięcia pojawiły się w odległości 1/3 wysokości belki od jej górnej powierzchni.

Belka $n r$ 5. Gazożużlobetonowa belka. Zbrojenie o wyglądzie U-podobnego przestrzennego wzmocnienia ze stalowej spawanej siatki w dolnej części belki pod gazbetonowym rdzeniem. Obszar U-podobnego wzmocnienia sięga do 1/2 wysokości gazobetonowego rdzenia belki. Przy obciążeniu 4,50 kN maksymalne ugięcie belki wyniosło $1,34 \mathrm{~mm}$. Drugi etap pracy belki betonowej rozpoczął się przy obciążeniu 4,15 $\mathrm{kN}$, ugięcie przy tym wyniosło $1,26 \mathrm{~mm}$. Przy obciążeniu 4,78 kN belka została zniszczona. Analogicznie jak i w belce $\mathrm{nr} 4$, przy zwiększaniu obciążenia pojawiły się poziome pęknięcia, chociaż dominującym było też pionowe pęknięcie.

Belka $n r$ 6. Gazożużlobetonowa belka. Zbrojenie o wyglądzie U-podobnego przestrzennego wzmocnienia ze stalowej spawanej siatki umieszczonej w dolnej części belki pod gazbetonowym rdzeniem. Obszar U-podobnego wzmocnienia sięga na całą wysokość gazobetonowego rdzenia belki $(80 \mathrm{~mm})$. Przy obciążeniu 4,50 $\mathrm{kN}$ maksymalne ugięcie belki wyniosło 1,06 $\mathrm{mm}$. Drugi etap pracy belki betonowej rozpoczął się przy obciążeniu 4,20 $\mathrm{kN}$, ugięcie przy tym wyniosło $0,85 \mathrm{~mm}$. Przy obciążeniu 4,60 $\mathrm{kN}$ belka została zniszczona (uległa złamaniu).

Belka $n r$ 7. Gazożużlobetonowa belka. Zbrojenie wykonano $\mathrm{w}$ postaci przestrzennego wzmocnienia ze stalowej spawanej siatki, którą umieszczono wokół gazobetonowego rdze-nia belki. Przy obciążeniu 4,50 kN maksymalne ugięcie belki wyniosło $1,37 \mathrm{~mm}$. Drugi etap pracy belki betonowej rozpoczął się przy obciążeniu $4,28 \mathrm{kN}$, ugięcie przy tym wyniosło $1,28 \mathrm{~mm}$. Przy obciążeniu $4,86 k N$ belka została zniszczona (uległa złamaniu).

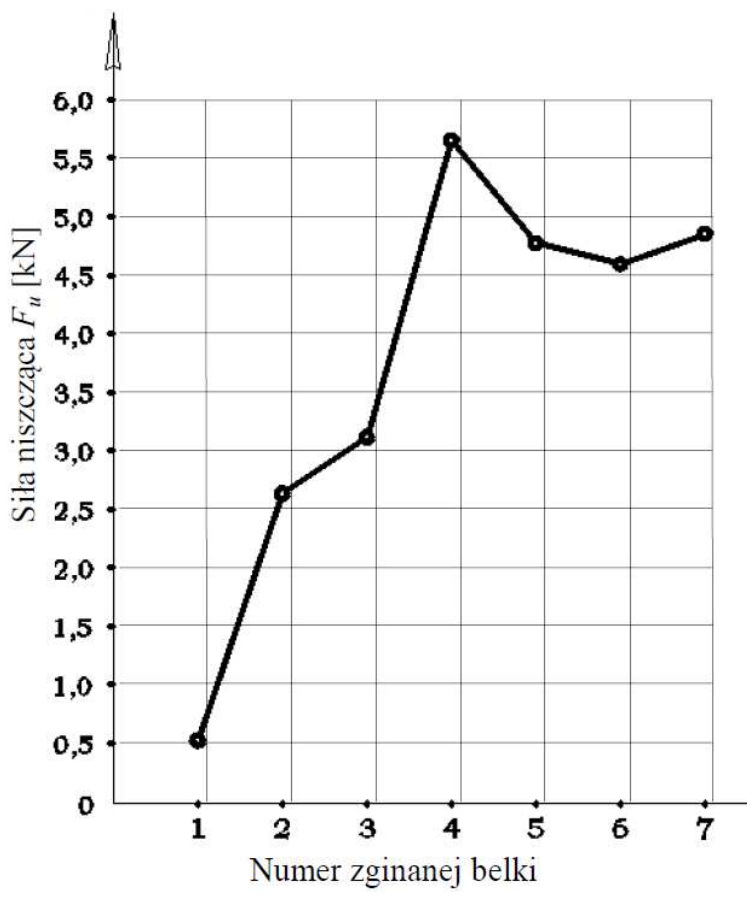

Rys. 6. Siły niszczące w badanych belkach

Fig. 6. Forces of destroying in the tested beams 
Na rysunku 6 pokazano wartości siły niszczącej $F_{u}$ dla poszczególnych belek. Natomiast na rysunku numer 7 pokazano dla poszczególnych próbek zależność ugięcia belki od przyłożonego obciążenia.

Największą siłę niszczącą osiągnięto w belce numer 4. Jest to belka, w której zbrojenie umieszczono w dolnej części belki i wykonano w kształcie U-podobnego przestrzennego wzmocnienia ze stalowej spawanej siatki. Wygięcie siatki sięga do 1/3 wysokości gazobetonowego rdzenia belki. Zwiększenie wysokości wygięcia siatki na bocznej powierzchni (na 1/2 wysokości gazobetonowej belki lub na całą wysokość belki), lub wykorzystanie obwodowego zbrojenia gazobetonowego rdzenia, nie spowodowało w zasadzie przyrostu nośności belki.

Analizując ugięcia można zauważyć, że najlepszy rezultat otrzymano przy badaniu belki nr 6 (zbrojenie wykonano w kształcie U-podobnego przestrzennego wzmocnienia ze stalowej spawanej siatki na całą wysokość gazobetonowego rdzenia). Belka ta wykazała najmniejszą wartość ugięcia spośród wszystkich badanych próbek.

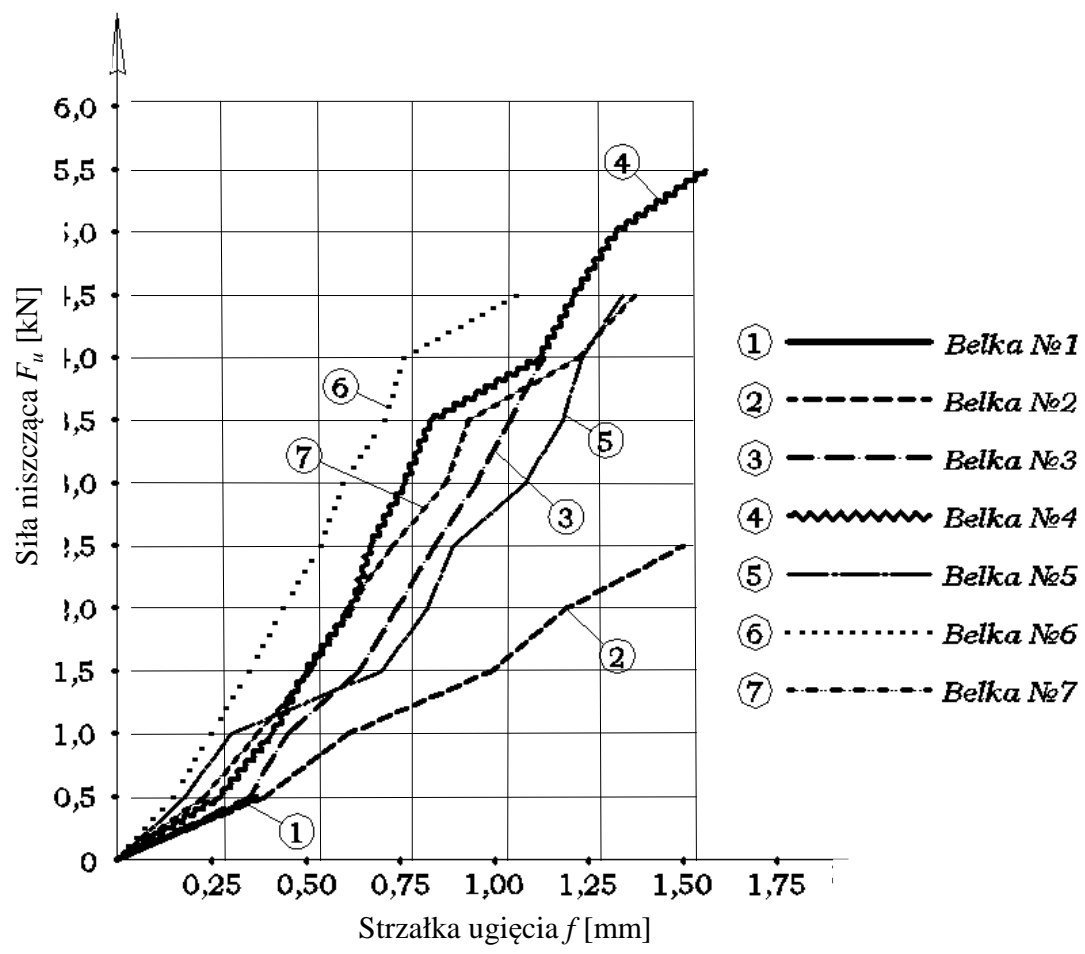

Rys. 7. Zależność między siłą niszcząca $F_{u}$ a ugięciem belki $f$

Fig. 7. Dependence between the destroying force and the deflection of the beam 


\section{Wnioski}

Na podstawie przeprowadzonych pilotażowych badań eksperymentalnych belek wykonanych $\mathrm{z}$ gazobetonowego rdzenia $\mathrm{z}$ niekonwencjonalnym zbrojeniem i żużlobetonową warstwą ochronną można sformułować następne wnioski: 1. W wyniku przeprowadzonych badań eksperymentalnych określono pozytywny wpływ zbrojenia w postaci spawanej siatki na pracę zginanych gazożużlobetonowych belek.

2. Gazożużlobetonowa belka z U-podobnym przestrzennym zbrojeniem ze stalowej siatki spawanej, $\mathrm{z}$ wygięciem na $1 / 3$ wysokości gazobetonowego rdzenia, wykazała najlepsze rezultaty. Miała np. od 16\% do 45\% późniejszy czas rozpoczęcia tworzenia się pęknięć przy takim samym obciążeniu jak pozostałe belki. Charakteryzowała się ponadto największą wartością niszczącego obciążenia w porównaniu z belkami zintegrowanymi z innymi schematami zbrojenia oraz o 53\% większą wartością obciążenia niszczącego w porównaniu z belką zintegrowaną bez zbrojenia. Najlepszy rezultat przy badaniu ugięcia otrzymano dla belki ze zbrojeniem U-podobnym wykonanym ze stalowej spawanej siatki z wygięciem na całą wysokość gazobetonowego rdzenia.

3. Istnienie zbrojenia wykonanego $\mathrm{w}$ postaci U-podobnego przestrzennego wzmocnienia ze spawanej siatki pozytywnie wpływa na nośność zginanych gazożużlobetonowych konstrukcji wyłącznie do pewnej granicy. Zwiększenie wysokości wygięcia siatki lub wykorzystanie obwodowego zbrojenia gazobetonowego rdzenia nie spowodowało oczekiwanego przyrostu nośności belki.

4. Na podstawie otrzymanych eksperymentalnych danych można zaproponować następujące rekomendacje do stosowania spawanej siatki przy zbrojeniu gazobetonowych belek z warstwą ochronną z żużlobetonu:

a) spawana siatka stalowa całkiem dobrze może spełniać zadanie zbrojenia wzmacniającego;

b) najbardziej korzystnym z zaproponowanych wariantów zbrojenia jest stosowanie spawanej siatki w kształcie U-podobnego wzmocnienia, które wychodzi na $1 / 3 \div 1 / 2$ wysokości przekroju gazożużlobetonowej belki, gdyż podane sposoby zbrojenia powodują najlepsze charakterystyki wytrzymałościowe elementów oraz wpływają korzystnie na wartości otrzymywanych ugięć belek.

Przeprowadzone badania eksperymentalne miały jedynie charakter pilotażowy. W celu sformułowania obiektywnych wniosków dotyczących gazożużlobetonowych belek, należy przeprowadzić serie badań o dużo większej liczebności próbek.

\section{Literatura}

[1] Бабич Е.М. Конструкции из легких бетонов на пористых заполнителях. К.: Выща школа, 1988. - 207 с. 
[2] Исследование ячеистых бетонов и конструкцій: Сб. науч. тр. / Гл. ред. Серых Р.Л.; ред.. Муромский К.П. - М.: НИИЖБ, 1989. - 111 с.

[3] Кривицкий М.Я. Ячеистые бетоны (технология, свойства и конструкции) / М.Я.Кривицкий, Н.И.Левин, В.В.Макаричев - М.: Стройиздат, 1972. - 137 с.

[4] Опєкунов В.В. Пористі композиційні матеріали та їх використання у будівництві /В.В. Опєкунов. - К.:Академія будівництва України, 2006. $85 \mathrm{c}$.

[5] Паплавскис Я., Новикс Ю. Теплотехнические свойства стен из ячеистого бетона // Сб. науч. трудов. Вып. 2. Теория и практика производства и применения ячеистого бетона в строительстве. - Днепропетровск: ПГАСА, 2005. - С. 193196.

[6] Саницький М.А. Пінобетон на модифікованих портландцементах / М.А.Саницький, О.Р.Позняк, В.В.Ілів // VIII Міжнар. наук. конф. «Актуальні проблеми будівництва та інженерії довкілля», Львів, Кишице, Жешув, 6-11 жовтня 2003 р.: Зб. матеріалів конференції. - Л.: Вид-во Нац. ун-ту «Львів. політехніка», 2003. - С. 23-36.

[7] Патент України на корисну модель, u2014 11750 МПК Е04С 5/02 (2006.01). Пролітний газобетонний елемент 3 двостороннім вертикальним армуванням зварною сіткою / Фамуляк Ю.Є.; заявн. і патентовласник Львівський нац. аграр. ун-т - №99447, заявл. 30.10.2014; опубл. 10.06.2015. Бюл. № 11.

\section{EXPERIMENTAL RESEARCH OF LIGHT CONCRETE ELEMENTS, WHICH ARE REINFORCED WITH GRIDS}

\section{S u m m a r y}

Span constructive elements of foam-concrete and aerated concrete are performed similar as usual, reinforcement is performed by steel armature smooth or periodic profile. Experimental and theoretical research of comprehensive light concrete span elements and other types of reinforcement, their use in the methods of calculation such the constructions with untraditional reinforcement are not explored and used enough. One way to solve the problem - replacing traditional reinforcement to untraditional one (for example, organic or biological materials, different kinds of grids). The results of experimental and theoretical research of slag aerated concrete bent elements, the features of their work under the load are presented in this article.

Keywords: aerated concrete, slag concrete, untraditional reinforcing, strength, load bearing capacity, deformation

Przestano do redakcji: 07.06.2016 $r$.

Przyjęto do druku: 30.06.2016 r.

DOI: $10.7862 / \mathrm{rb} .2016 .48$ 